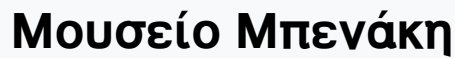

A Singular Antiquity: Archaeology and Hellenic Identity in Twentieth-Century Greece

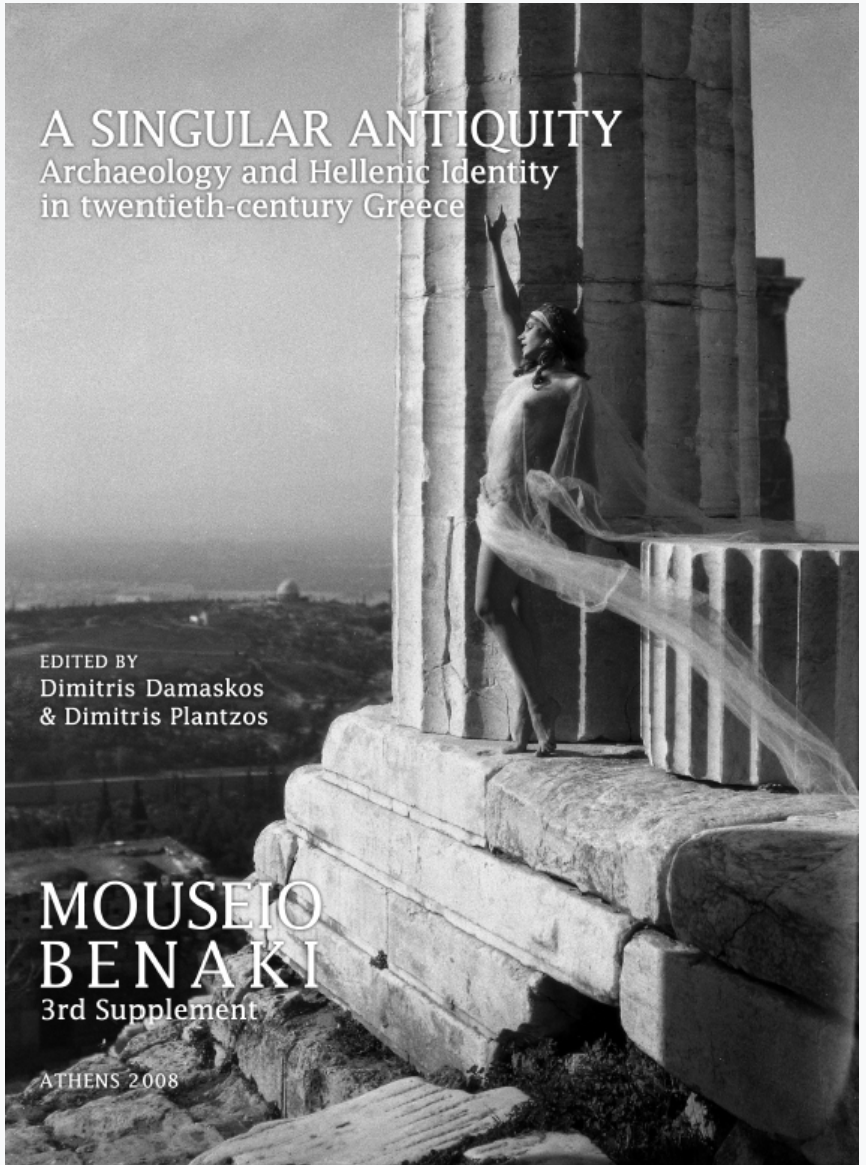

The discourse on Hellenicity, historical continuity and the Greek Left

Angeliki Koufou

doi: $10.12681 /$ benaki.18052

Copyright @ 2018, Angeliki Koufou

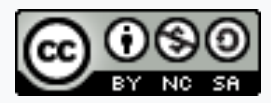

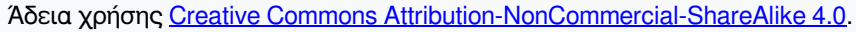

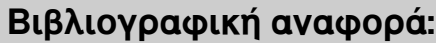

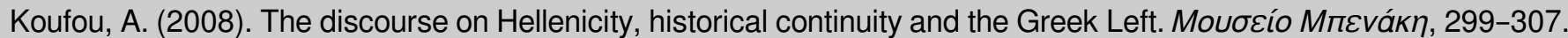
https://doi.org/10.12681/benaki.18052 


\section{The discourse on Hellenicity, historical continuity and the Greek Left}

THE DisCOURSE ON HELlENICITY was shaped during the inter-war period along different intellectual trajectories. Rather than being the unique achievement of what has been called the 'generation of the thirties', this discourse was more like a palimpsest, in other words a locus on which different traditions articulate with one another enabling us to detect the interpenetration of ideological and aesthetic positions and the fluidity of their boundaries. ${ }^{1}$ As Artemis Leontis rightly observes, this discourse reflected the dominant form of aesthetic nationalism which identified Hellenism with the physical landscape of the Greek peninsula, not with the Greek nation at large (a great portion of which was yet to be redeemed). ${ }^{2}$ This aesthetic and historical position drew on the indigenous ideal' of Periklis Giannopoulos, who saw cultural creativity as based on the aesthetic value of the Greek landscape. ${ }^{3}$ The reason why I refer to these issues, already discussed by A. Leontis and D. Tziovas among others, is because they set the parameters for the discussion which follows and in order to look again at certain aspects of the debate. For example, the discourse on Hellenicity takes the geophysical landscape as the locus where all phases of Greek history intersect and become part of a whole. In this context historical continuity is effected through the unity of the landscape. Yet, this view is not complementary to other ideas on Greek national cohesiveness. Although the 'geo-climatic' theory shared the belief in the uniqueness and superiority of the Greek nation - which as Leontis argues involved a radical transformation from the ideal of the humble nation to the vision of transcendental nation ${ }^{4}$ - it emphasized the local and physical dimension of the nation rather than its spiritual and supra-local nature as the nationalist historians of the nineteenth century, most notably Konstantinos Paparrigopoulos, had done. 5 The presence of landscape in the thought of Periklis Giannopoulos was incompatible with the nationalist ideology of Ion Dragoumis ${ }^{6}$ for example, or, for that matter, with the dominant version of the 'Great Idea'.

The discourse on Hellenicity was specific to the historical conditions that followed the final defeat of Greece in 1922, the collapse of the nationalist project, and the reduction of Greek territorial ambitions to Greece proper. However, as mentioned above, this discourse was like a palimpsest where different ideological trajectories intersected and for this reason it is necessary to deconstruct it in order to reveal the circumstances of its production as well as the channels through which it affected the theory and cultural practice of the Greek Left. At this point the reader should be reminded that the generation of the thirties, the influential group of liberal intellectuals who moved beyond demoticism and faced up to the challenge of Marxism, played a major role in shaping the discourse on Hellenicity. The fact that an intellectual movement, such as that of the generation of the thirties, which positioned itself in the modernist avant-garde and introduced cosmopolitanism to the literate Greek public, ended up as the champion of Hellenicity and led to the almost paganistic worshipping of the Greek landscape, as Leontis claims, ${ }^{8}$ demands an explanation. This retrogression was caused by a number of factors. First, there were the historical conditions that followed the creation of the modern Greek state and shaped the Greek national and cultural 
identity. Secondly, it owes something to the influence of a pre-existing set of traditions which, one way or another, had generated the discussion about Hellenicity. Finally, we should not overlook the strong urge to create an indigenous and autonomous point of reference (entopia) as an answer to the heterotopian visions of Greece concocted by the Western appropriations of Classical Greece.'

The need to forge a coherent and self-sufficient Greek cultural identity was made all the more urgent by the uncertain historical and political progress of the scrappy modern Greek state. As Tziovas claims, maybe herein lies the reason why the ambitious and contradictory project of the liberal intellectuals, which was meant to reconcile demoticism and cosmopolitanism, modernity and tradition, retrogressed and lost its avant-garde vigour. ${ }^{10}$ As for the preexisting traditions affecting the making of the discourse on Hellenicity, they were related to the discussions on the nature of 'national art' that had taken place during the twenties, ${ }^{11}$ to intellectual conflicts regarding the modern, ${ }^{12}$ and finally the demoticist tradition. Demoticism in particular, and the high regard it had for folk culture, exerted a constant influence over the aesthetic thought of both Marxists and liberals. One can also find the marks of the authoritarian Metaxas regime on the palimpsest of Hellenicity. Under the aegis of the regime of 4th August Hellenicity was deprived of every element of aesthetic creativity. Despite the fact that officially the regime promoted folk culture, in fact it only paid lip service to it. The transformation of popular culture from a creative activity to an absolute nationalist value to be guarded by the nation led to its ossification. In addition, this transformation was directly affected by discourses which emphasized biological and geographical factors as determining the state of Greekness. ${ }^{13}$

At first, the discourse on Hellenicity and the emphasis it put on the cultural authority of the Greek landscape on national aesthetics, seemed to have no influence among Greek left-wing intellectuals during this period. The Left condemned the notion of racial and geophysical unity and continuity of the Greek nation as metaphysical and unfounded; but this did not last. The gradual abandoning of internationalist values and avant-garde forms in art in favour of more conservative aesthetic choices, and the move towards folk culture, were an outcome of the hardening of the Greek Communist Party line and the shaping of a new aesthetic and literary canon founded upon socialist realism. This charge can be examined by taking the left-wing and socialist reviews as a case in point, particularly these with strong ties with the Greek Communist Party (hereafter: KKE) like Nea Epitheorisi ('New Review') and Protoporoi ('Pioneers'). In these reviews pluralism of opinion, breadth of acceptance of artistic and specifically of avant-garde innovation were inversely proportional to the ties with the party machine. In fact, approval of some versions of Hellenicity in some of these reviews was the outcome of the direct influence of left-wing politics on aesthetics.

Until 1931 party control over Nea Epitheorisi and Protoporo $i$ was weak and both reviews collaborated with a large number of left-wing and socialist intellectuals, such as Hourmouzios and Rantos, who had no official association with the KKE. ${ }^{14}$ However, the situation in Europe, particularly the rise to power of Fascism in Germany and elsewhere, along with developments in the USSR, the defeat of Trotsky and the establishment of Stalinism, created a novel situation, which directly affected cultural conflicts and the circulation of ideas in Greece. Pressed between Fascism and Stalinism, the aesthetic tenets of both liberals and communists in Greece began to converge to the paradoxical point where Metaxas, Ritsos and Elytis meet in the worship of youth, health and happiness. ${ }^{15}$ It is interesting to follow the steps in this convergence of sorts whereby the interweaving of political priorities determined aesthetic choices. The selection by the leadership of the Third International of Nikos Zahariadis as the new communist leader in Greece was of major importance. Zahariadis realigned the Party position on the social structure of modern Greek society, the duties of the KKE and the nature of revolution. ${ }^{16}$ In contrast to their earlier position, the new leadership claimed that the bourgeois-liberal transformation of Greek society was yet to be achieved. As a consequence the Party's duty was to channel revolutionary activities into fulfilling this stage before redirecting these activities to proletarian, socialist objectives. ${ }^{17}$

As far as the socialist reviews were concerned, their dependence on the Party led to their cutting every link with non-Marxist intellectuals as well as regarding all those who did not follow Party line with disfavour. The course of these reviews seems pre-determined as it retrogressed to the vindication of socialist realism. Thus, from discussing proletarian literature, or realism as a means of positively representing heroes and role-models and the party involvement of artists and writers, the review Neoi Protoporoi shifted its attention to the tenets of socialist 
realism which embraced and enriched these values and artistic principles. ${ }^{18}$ Moreover, the renouncing of the artistic avant-garde in the Fourth Congress of Soviet Writers, in 1934, was also crucial. Following Maxim Gorky's speech, the Congress exalted folk culture and literary tradition as the true expression of the soul of the people and as a source of inspiration which all communist intellectuals should follow. ${ }^{19}$ In my view this is the point where the direction taken by the Greek Left intersected with the discourse on Hellenicity. At this point, communists, liberals and conservatives found common ground in exalting artistic folk creation and rejecting foreign influences. ${ }^{20}$ Folk culture came under the scrutiny of communist artists through the work of former demoticists and now communist intellectuals like Dimitris Glinos and Nikos Karvounis, who valued heritage as the link between the Greek Revolution of 1821 and the social struggles of their own time. ${ }^{21}$

Despite the complete divergence and even violent confrontation between the Metaxas regime and the political and social goals of the Greek communists, both invoked the same artistic models and used a similar language on folk culture. For example, en extract from Neoi Protoporoi, 'Get close to the masses. Get as close as you possible can, live their lives, their aspirations, their struggles, speak their language to them. It is the only way to touch the soul of the masses' ${ }^{22}$ closely echoes Metaxas' statement that 'We need to go back to the fountain of the Greek civilization to baptize ourselves in its pure and clear water and become Greeks', ${ }^{23}$ or that 'If you aspire to write long-lasting texts [first] reach for the inexhaustible spring of the popular soul. Approach the labouring people [...] to hear clear the climax of their feelings [...]'.24

Populism in artistic expression was inscribed in the populist turn the KKE took, in theory and practice, after Nikos Zahariadis rose to the Party leadership and radically reoriented the communist strategy in Greece. The Sixth Plenum of the Central Committee of the KKE, held in January 1934, pronounced the bourgeois transformation initiated in the Greek Revolution of 1821 incomplete, due to the capitulation of the Greek bourgeoisie to the feudal classes, and declared it the duty of the communists to complete this transformation by mobilizing the working classes and the peasants. ${ }^{25}$ In this respect, KKE carried on the unfinished struggle and presented itself as the true heir of the National Revolution. Yannis Zevgos, a member of the Central Committee, took upon himself the task of popularizing this thesis with a pamphlet entitled Why the Revolution in Greece will be Bourgeois-Democratic? ${ }^{26}$ and countering the Marxist historian Yannis Kordatos whose work on the bourgeois nature of the Greek Revolution expressed the former Party position. ${ }^{27}$

The KKE took a populist turn, when it adopted the political analysis and strategy of the Third International. ${ }^{28}$ According to Philippos Iliou, the meaning of the term 'people' was extended to cover almost every aspect of Marxist analysis of social reality. As a result, social conflicts were simplified and pressed to fit into the bipolar schema pro-/anti-people which replaced all other class definitions. ${ }^{29}$ 'Still present today among many leftist intellectuals, this populist tradition, concocted in the troubled years of the thirties, elevated the "people", a fluid category, to the status of protagonist in a uniform and coherent modern Greek tragedy'.

The emphasis on folk culture propelled the Left into a direct dialogue with the discourse on Hellenicity. However, the Greek Left used folk culture and Hellenicity as a critique of the 'Great Idea' and its assumption that national territorial unification was a vital precondition for any meaningful internal modernization. ${ }^{30}$

The Greek Left was not alone in its hostility towards the 'Great Idea' because many liberal intellectuals had espoused this position as well. However, by closely following the communist historical and political analysis in the thirties one could come to the conclusion that thanks to this populist turn the Party had developed an idealized indigenous perspective to confront the 'Great Idea', which it considered alien to the true interests of the people. It must be noted at this point that the KKE considered the 'people' in very broad terms and included in this body all national minorities, ${ }^{31}$ without ceasing to believe in an indigenous and authentic people's culture radically different in nature from the elements promoting the 'Great Idea'. As Nikos Zahariadis claimed in his Theses on the History of the $K K E,{ }^{32}$ the 'Great Idea' was a way of exploiting the Greek people, to the advantage of those bourgeois and feudal classes that served foreign interests, and for this reason totally alien to the [national] tradition of the Greek Revolution. ${ }^{33}$ Thus, the KKE shaped its patriotic profile by combining the indigenous with the popular and setting this against its political opponents whom it portrayed as dependent on foreign powers. By presenting itself as the authentic heir of the popular tradition of 1821 and as 
responsible for fulfilling the unfinished project of bourgeois modernization, the KKE created its own patriotic repertoire to counter the accusations of unpatriotic action levelled against it by the Metaxas regime. In short, within the political conditions of the regime of the 4th of August, and possibly as an outcome of its turn towards Stalinism, the internationalist profile of the KKE was reduced in favour of a distinctly patriotic character.

The policy of a popular front that the KKE followed from the eve of World War II to the end of the German Occupation of the country in 1944, as well as the Party's fundamental role in the Greek Resistance movement through EAM (the National Liberation Front) and ELAS (the National People's Liberation Army), its military arm, boosted its patriotic and populist orientation. In his closing speech to the Seventh Congress of the KKE, Nikos Zahariadis, once more claimed that the patriotic character of the Party ensured its leading role in achieving popular unity during the Occupation and making the Greek Resistance a success equal only to the Revolution of 1821 . Zahariadis insisted on the connection between the bright past and the elusive present, by directly comparing the Party members (tous koukouedes) with the 1821 revolutionaries. As he put it: 'the fighter of ' 21 would not hesitate to take the same oath as the ELASites of our days..$^{34}$ In addition, Zahariadis referred to the ideals of the Party which were derived from the nation and the people as well as its will to achieve national liberation and contribute to peace. In the predicament of this specific historical situation, the prospect of social revolution and radical transformation of society had to wait.

Until 1945 the official Party line supported the thesis that the roots of the modern Greek nation could be found in Late Byzantine times. As Zahariadis claimed: 'this was the time when the Greek nation emerged, and forged itself as a consequence of endless national and democratic struggles. ${ }^{35}$ In this sense Zahariadis distanced himself and the Party from the widespread (nationalist) belief in the historical continuity of the Greek nation from Antiquity to the present. Modern Greece was no heir to the slave-owning society of ancient Greece or the feudal Asiatic Byzantine Empire.

KKE's defeat in the civil war created a new critical condition that also affected the Party's historical outlook. In the years following the end of the civil war the Party felt the urge to revise its own position on the Greek history and sought to establish its own 'progressive' and 'peoplegrown' version of historical continuity. This move was deemed necessary to justify the contribution of the Party to the Resistance movement and its patriotic character, both under the criticism, even the slander, of the victorious Right which missed no opportunity to recall the 'unpatriotic' communist position over the issue of Macedonia and the KKE's dependency on the Soviet Union. The language of class was gradually abandoned in the political and theoretical analyses of the KKE in favour of abstract references to the 'people', the 'nation', or to social distinctions bereft of class connotations, such as 'progressives' vs. 'reactionaries', or 'the people' vs. 'the plutocracy'. Under the burden of defeat, political persecution, the forced emigration of thousands of Party members and sympathizers, and post-civil war conditions in general, the KKE leadership devised a new strategy which 'set the task of forming a broad pan-Hellenic, patriotic movement to throw off the American yoke Greece was under'. ${ }^{36}$ This strategy, which was finally rejected, ${ }^{37}$ was presented in the Draft Programme of the KKE in $1954,{ }^{38}$ and was combined with a revision of the Party's historical approach, as a means of countering the criticism of the Right and of reciprocating. More specifically, the Draft Programme referred to historical continuity as the site where Antiquity, Byzantium and the modern times harmoniously cohabited, and where 'the people's epic' took place. The Draft included a long historical section discussing the history of the Greek nation diachronically. According to the Draft:

'From an historical and ethnographic point of view the dominant Graeco-Roman [graikike] ethnie [laoteta] in Byzantium ${ }^{39}$ was as connected to the Ancient Greek and Hellenistic period as it was to the East Roman Empire and the Orthodox Church. This ethnie was composed of the mass of the peasants and the poor who spoke the same language [demotic Greek], shared the same religion [Byzantine Orthodoxy] and lived in the same area. The transformation of the Graeco-Roman ethnie to a nation and the forging of a national consciousness in the conditions of the declining Byzantine Empire were expressed in Greek folk creations, for example in texts such as the epic Digenis Akritas and the legend of the Marmaromenos $\mathrm{Va}$ silias' ['King turned to stone', the last Constantinopolitan Emperor, who is bound to rise again when the time is ripe, to liberate the City and its people]. ${ }^{40}$ 
In another part the Draft combined harsh criticism of the 'Great Idea' with a selective use of historical continuity - 'our distant and recent past'. The people, and democratic forces in Greece, were considered the only true heirs of this glorious past. 'We [the communists] do not deny the good and beauty that came out of Ancient Greece and Byzantium. We honour Thales, Anaxagoras and Anaximenes, Protagoras and Heraclitus, Democritus and Epicurus, the zealot movement, Plethon and many others. ${ }^{31}$

The Draft did not simply introduce a people-grown version of historical continuity; it followed a very conservative orientation by announcing the Graeco-Roman ethnie and its trajectory through time as a substitute for historical continuity. Thus the genealogy of the 'three-thousand-yearold historical continuity' was enriched with a new version, the communist one! This is precisely what Dimitris Hatzis, a left-wing intellectual in exile, stated in his critique of the Draft Programme. Hatzis censured the Draft because it concocted a new 'Great Idea' that moved through time on a thin line of 'Greek progressiveness' linking the Party's Draft Programme directly with Heraclitus. ${ }^{42}$ According to him the Draftlacked serious documentation and, thus, its main thesis on historical continuity and the transformation of the Graeco-Roman ethnie to a nation was totally unconvincing. Hatzis added that racial continuity was an extremely poor substitute for historical continuity and it had been abandoned even by bourgeois and liberal intellectuals who preferred culture over race, and was no more convincing due to lack of documentation. ${ }^{43} \mathrm{He}$ did not limit this critique to those editing the Draft but extended it to include the young and promising left-wing historian Nikos Svoronos whose History of Modern Greece followed a similar line of argumentation. ${ }^{44} \mathrm{Hatzis}$ included Svoronos in the group of bourgeois historians because, as he claimed, he followed Voutieridis and Dimaras and argued in favour of historical continuity without scientific justification.

Indeed, in his book and in a short paper published in Epitheorisi Technis in 1955, ${ }^{45}$ Svoronos failed to put forward a convincing argument. ${ }^{46}$ It is true that he emphasized the qualitative and thus differential dimension of the adjectives (Ancient - Medieval - Modern) usually attached to the different periods of the Greek nation. However, his argument made sense only if enough room was left to a latent cultural entity, called 'Hellenism', to move over time, with its core intact. ${ }^{47}$ Of course, Svoronos' work has been prolific and influential and cannot be reduced to a short text outlining the history of Greece. I am tempted to suggest that the argument presented in this particular text - and possibly similar statements he made at a later stage - was a kind of patriotic gesture similar to the one made in the Draft Programme.$^{48}$ By appropriating historical continuity Svoronos underlined the contribution of the people to Greek history and rehabilitated the forces of progress, the Left in particular, into the national body from which it was excluded after its defeat in the civil war.

Although Hatzis might have shared this hidden argument, he was extremely reluctant to accept any form of continuity, particularly the appropriation of ancient Greece, which he saw as the basis of the 'Great Idea'. ${ }^{49}$ Hatzis was strongly critical of this approach and did not hesitate to expose its similarities with 'bourgeois' versions of historical continuity. His own research on a large body of literary texts from different periods led him to believe that no form of continuity could be argued for the period prior to the last centuries of Byzantium. ${ }^{50}$ On the other hand, Hatzis' criticism should not be seen in isolation from the mounting criticism of the Stalinist KKE leadership, endorsed by many Greek communists. Hatzis did not deny that his historical interpretation was political in nature. ${ }^{51}$ However, he was also concerned that his argument be founded on scientific - in his case literary - evidence and sound methodology. From this point of view Hatzis' argument is totally different from the rigid Party analyses that were used to make historical interpretation fit with the current political policy of the Party. The authority of the dominant discourse on historical continuity revealed itself in the similarities between the nationalist and communist discourses, as shown by Hatzis..$^{52}$

The post-civil war regime took a heavy toll on the Greek Left. The increased persecution sharpened the sense of defeat among Greek leftists and polarized internal dissent in the Greek Left. The official discourse of the Party became more rigid and conservative while internal dissent proliferated. It was in this context that, in December 1954, a new review, the Epitheorisi Technis, was first published, presenting itself as 'an artistic review that aspires to present its readers with fruitful philosophical and aesthetic thinking. ${ }^{53}$ The editors of the review, all young and in search of a more radical form of expression, were allowed few liberties. Particularly between 1955 and 1961 the long arm of the Party made its presence felt through an older generation of left-wing intellectuals, with more rigid and populist views, 
who played an active part in the review. During these years issues such as 'people's art', 'demotic songs', and the 'traditions of 1821' often figure in the pages of the review. This choice was not neutral. The people and its qualities were once again announced as the touchstone of artistic creativity. In the first issue the review hosted the views of Yannis Tsarouchis, who stressed the need for the creative transformation of tradition, ${ }^{54}$ along with that of Agis Theros who championed a traditional form of populist and patriotic demoticism and as he put it: 'Our authentic artistic traditions bear the mark of our holy race'.55 The review published extensively on the Greek Revolution of 1821. A theme issue on this subject appeared in March 1955, while the theatrical play Kolokotronis by Vasilis Rotas was also published in instalments in this same year. ${ }^{56}$ The interest the review took in the Revolution of 1821 was not only historical in nature. Comparing the Revolution with the Resistance was part of the strategy to rehabilitate the KKE as a patriotic force. Although the prospect of rehabilitating the KKE into the national body mobilized the Left as a whole, in the Epitheorisi Technis this task was undertaken by the older generation of intellectuals who had less formal ties with the Party, like Vasilis Rotas, Dimitris Photiadis and M.M. Papaioannou. This group openly subscribed to the logic of historical continuity. For example, Rotas found in the poetry of a young poet a link with both Homeric poetry and modern folk songs, while Papaioannou claimed that his anthology connected the modern reader with the Greeks of ancient Greece, the Middle Ages and the Tourkokratia (i.e. the period of Ottoman domination).$^{57}$ It is interesting to note that these views combined a simplistic historical approach with a total lack of political and ideological analysis..$^{58}$

After 1958, and more particularly after 1961, the number of theme issues was reduced, a sign that the younger members of the editorial committee had strengthened their position. They took upon themselves the task of promoting modern art and new forms of artistic expression, while at the same time they resisted the official Party line on art by rejecting socialist realism..$^{9}$ On many occasions, as for example in book reviews, the members of the editorial committee directly attacked 'all vulgar perceptions of the popular and the progressive,, ${ }^{60}$ and some of them went as far as to question the prevalent political ideology of the Party, the ideology of 'national liberation', on the grounds that it diluted social classes and class conflicts into broad terms like 'the nation' and 'the people'. ${ }^{61}$ I will not discuss the case of the Epitheorisi Technis any further. The reason why this paper refers to this review is to mention, at the risk of over-simplification, its vital contribution to the political and aesthetic culture of the Greek Left in spite of the polarized conditions of the period, which limited criticism to the Party line and censored dissenting voices.

Today one may wonder about the authority of a rhetoric overstressing 'the burden of the unique and chosen nation', a rhetoric broadcasted through official channels, schools and religious institutions, on the Greek society. Living in times of gratuitous, opportunistic even, ideological osmosis, when patriotic praise of the uniqueness and peculiarity of the Greek nation is promoted by politicians and public intellectuals in an obvious state of bewilderment as the remedy against globalization and its discontents - a rhetoric which can be encountered with in the discourse of diametrically opposed political parties, including the KKE - one might be legitimized in attempting a reassessment of Hellenicity. It is, perhaps, the genealogy of Hellenicity and historical continuity that could contribute to our understanding of the historical trajectory we have followed to arrive at our self-consciousness as a nation today.

Angeliki Koufou

Historian

harexe@sa.aegean.gr 


\section{Notes}

1. On Hellenicity (in Greek hellenikoteta, 'Greekness') see Lambropoulos 1987, 19-24; Tziovas 1989; Leontis 1995-1999, 107-18; Calotychos 1995, 119-30; Apostolidou 1995,131-46.

2. Leontis 1995, 85.

3. See the themed issue of Nea Grammata 1-3, 1938.

4. Leontis 1995,72 .

5. Tziovas 1989, 33 accepts the similarity between the two theories.

6. Dragoumis 1993.

7. Theotokas 1931; Theotokas 1939; Theotokas 1988; Theotokas 1994.

8. Leontis 1995, 128.

9. On the use of the term entopia, see Leontis 1995-1999.

10. Tziovas 1989, 52-53.

11. On the conflict concerning the national character of art see Theotokas 1988, 13- 35.

12. On the debate concerning modernity see Idea (January 1933 - March 1934), especially issues 8 (August 1933) and 15 (March 1934); Nea Grammata 16 (July 1935). See also Ladoyanni 1993.

13. On geo-climatic theory, see Tziovas 1988, 75-77; Vergopoulos 1979, 146; Peckham 2001, 76-88.

14. On Greek left-wing reviews, especially Nea Epitheorisi and Protoporoi, see Dounia 1999, 111-74.

15. Tziovas 1989, 146.

16. KKE 1987, 417-19. On factional struggles within the Communist Party ended by Zahariadis' victory, see Elephantis $1976,56-112 ; 112-38$.

17. Iliou 1976, 33.

18. Dounia 1999, 116-31; 219-33; 395-412.

19. Gorky 1934, 370; 373.

20. Karvounis 1935, 88-92; Hadjikyriakos-Ghika 1938, 127; Kyrou 1937, 101-8.

21. Dounia 1999, 420.

22. Neoi Protoporoi 1935, 43.

23. Metaxas 1971, 73.

24. Metaxas 1972, 841.

25. KKE 1987, 416-19; Zahariadis 1945a, 35-37.

26. Iliou 1976, 33.

27. Kordatos 1946.

28. Iliou 1976, 33-34.

28. Iliou 1976, 34 .

30. Zahariadis 1945b, 27-28.

31. Zahariadis 1945a, 37; 1945b, 30.
32. The manuscript was written in 1939 during Zahariadis' imprisonment but only published in 1945 .

33. Zahariadis 1945a, 19-28.

34. Zahariadis 1945b, 27-28.

35. KKE 1987, 416; Zahariadis 1945a, 19-20.

36. KKE 1954, 33.

37. According to Apostolidou 2003, 212, the fact that the patriotic front was not inextricably linked to the prospective of popular democracy was the cause of the rejection of the Draft Programme by the Russian Communist Party. KKE 1954, 3.

38. KKE 1954.

39. According to Petros Roussos 1955, 55-56, one of the main editors of the Draft, the term 'laoteta' was concocted after the Russian term 'narodnost' and the German 'Volkschaft'. Marxist classical theorists use the term 'nationality'.

40. KKE 1954, 6.

41. KKE 1954, 19.

42. Hatzis 1954,8

43. Hatzis $1954,4-8$.

44. Svoronos 1953.

45. Svoronos 1955, 208-12.

46. Svoronos 1955, 211.

47. Exertzoglou 2005, 107.

48. On Svoronos, see Svoronos 1988, 37-79; Liakos 1994, 171-99; Liakos 2001, 72-91.

49. Hatzis 1954, 8 considers ancient Greek civilization as universal heritage, whereas Roussos 1955, 65-66 attributes to Hatzis' views undue negativity towards the national ideas.

50. Hatzis 1954, 19-20.

51. Hatzis 1954, 3.

52. On Hatzis, see Hatzis 1995; Apostolidou 2003; Goulandris 1998; Goulandris 2001; Hatzis 2005; Kotzia 2006.

53. The left-wing review Epitheorisi Technis first appeared in December 1954 and its publication was violently interrupted by the dictatorship of the Colonels in April 1967.

54. Tsarouchis 1954, 55.

55. Theros 1954, 56.

56. Rotas 1955.

57. Rotas 1956, 264-65; Papaioannou 1961, 81; Politis 1996, 247.

58. Kremmydas 1996, 260.

59. Koufou 1996, 89-114.

60. Raftopoulos 1957.

61. Lykiardopoulos 1964, 460. 


\section{REFERENCES}

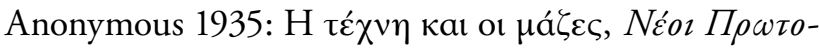
пóoo 2, 41-43.

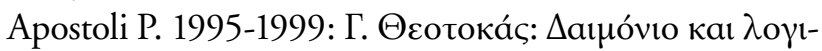

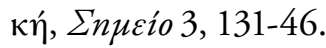

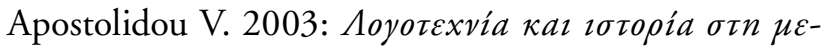

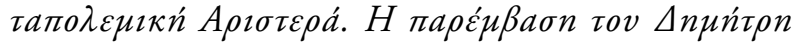

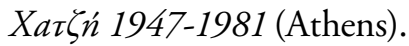

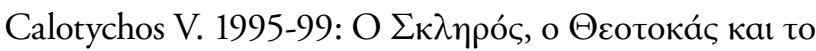

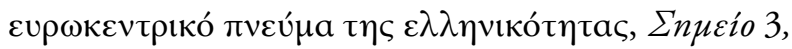
$119-30$.

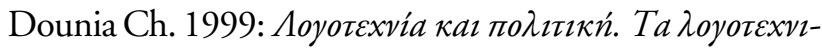

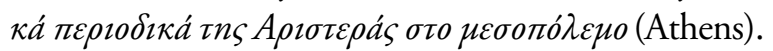

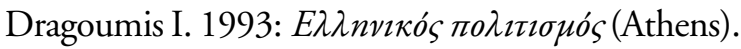

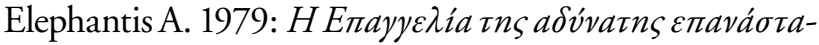

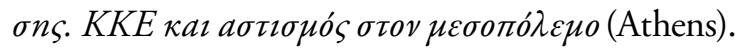

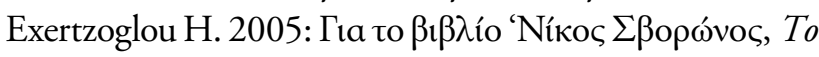

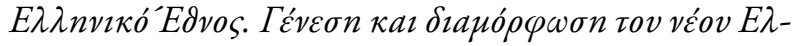

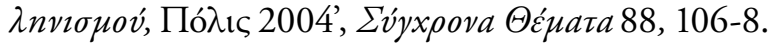

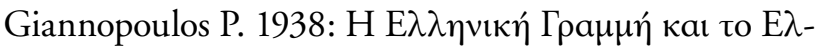

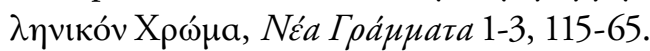

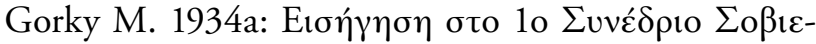

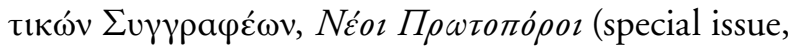
Sep.) 366-84.

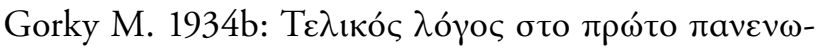

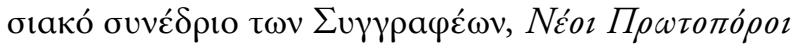
(special issue, Sep.) 385-94.

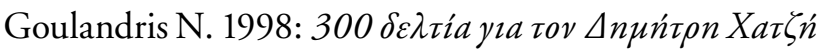
(Athens).

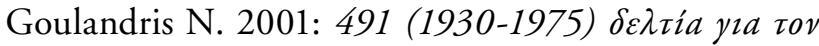

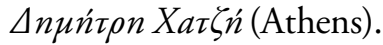

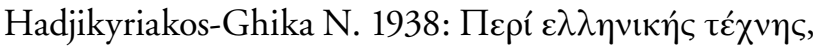
To NÉov Koátos 5, 126-32.

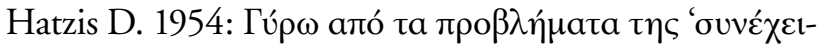
ac', Néos Kóouos 8, 1-20.

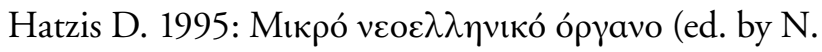
Goulandris; Athens).

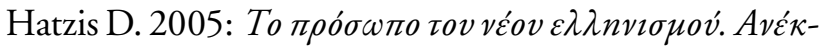

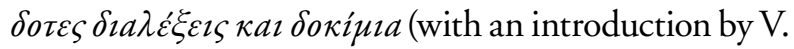
Apostolidou; Athens).

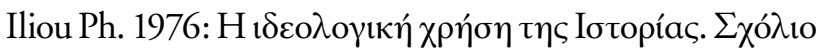

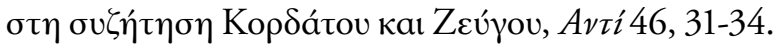

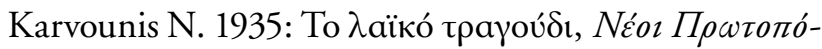

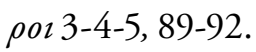

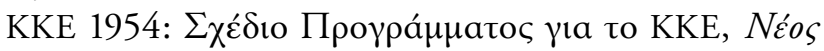
Kóouos 6, 1-43.

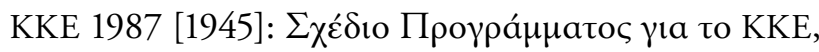

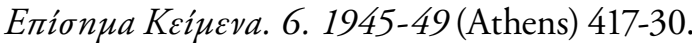

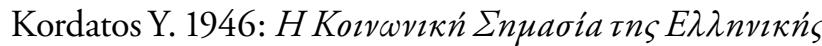

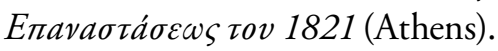

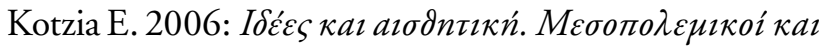

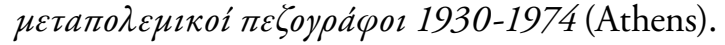

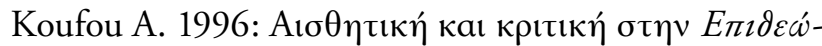

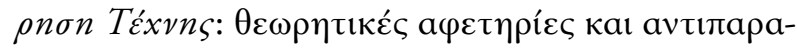

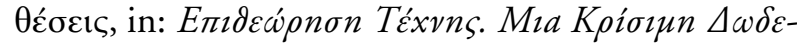

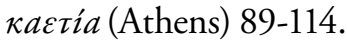

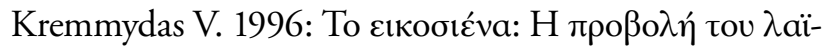

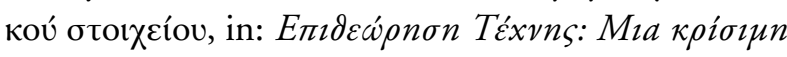
$\delta \omega \delta \varepsilon \kappa a \varepsilon \tau i a$ (Athens) 255-63.

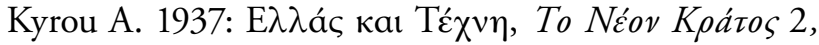
104-5.

Lambropoulos V. 1987: The aesthetic ideology of the Greek quest for identity, Journal of Modern Hellenism 4, 19-24.

Leontis A. 1995: Topographies of Hellenism: Mapping the Homeland (Athens).

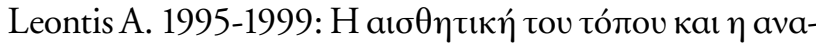

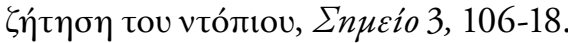

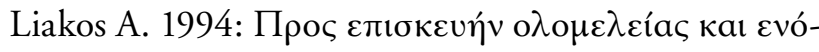

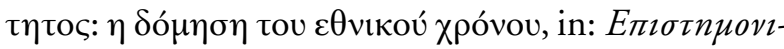

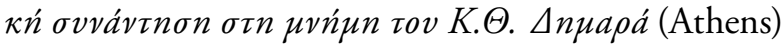
171-99.

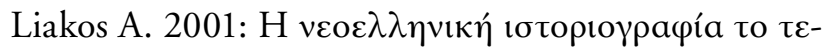

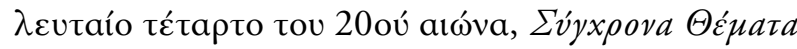
76-77, 72-91.

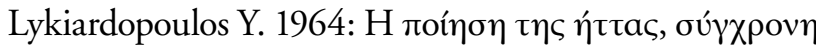

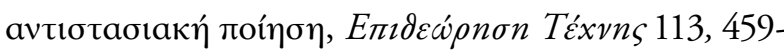
60.

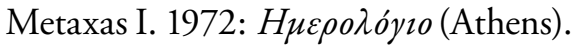

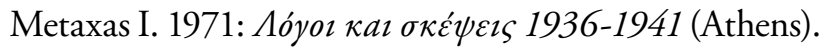

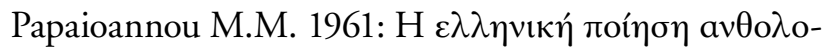

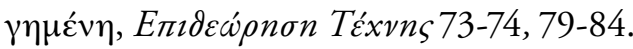

Peckham R.S. 2001: National Histories, Natural States: Nationalism and the Politics of Place in Greece (London and New York).

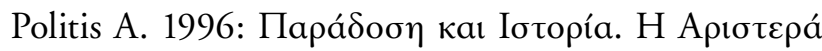

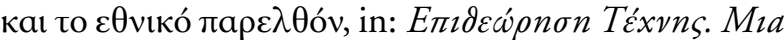

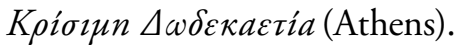

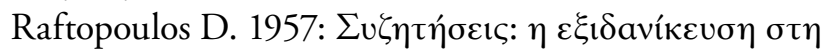

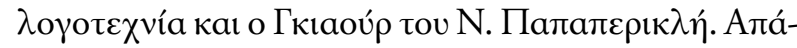

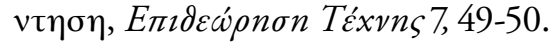




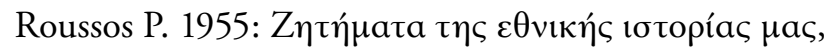
Néos Kóopos 10, 52-66.

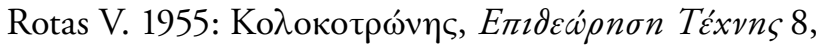
129-44; 9, 209-24; 10, 305-20; 11, 385-400; 12, 493503.

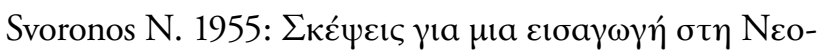

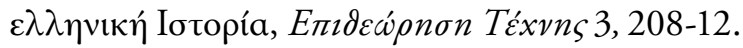

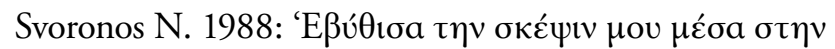

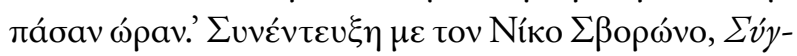

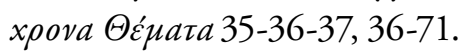

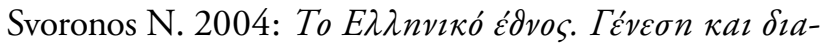

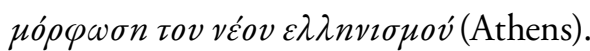

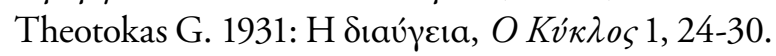

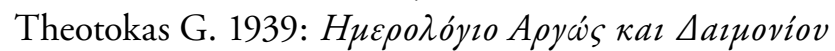
(Athens).

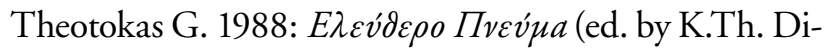
maras; Athens).

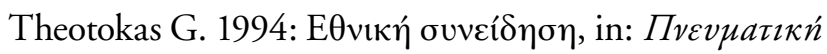
Пopcía (Athens) 48-68.

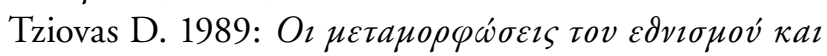

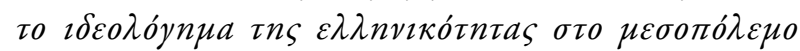
(Athens).

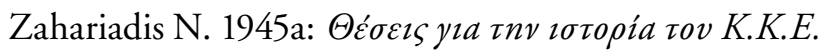
(Athens).

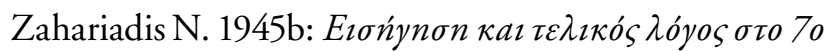

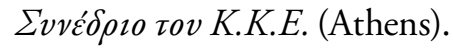

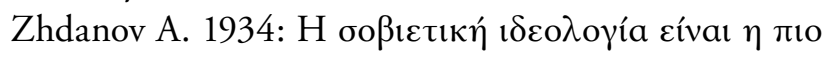

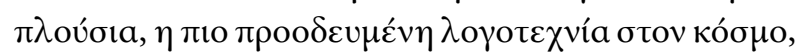

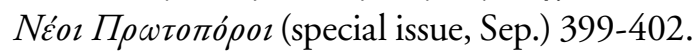


